\title{
WŁADYSŁAW GRZEŚKIEWICZ
}

\section{Prawne aspekty stosowania egzekucji administracyjnej z praw własności intelektualnej}

\section{Legal aspects of an administrative enforcement of intellectual property rights}

Streszczenie. W administracyjnym postępowaniu egzekucyjnym dotyczącym należności pieniężnych jednym ze środków egzekucyjnych jest egzekucja z autorskich praw majątkowych i praw pokrewnych oraz praw własności przemysłowej. Liczba zgłoszonych praw własności przemysłowej i zaległości podatkowych stanowi znaczne wielkości ${ }^{1}$. Administracyjny organ egzekucyjny $\mathrm{z}$ autorskich praw majątkowych i praw pokrewnych oraz praw własności przemysłowej korzysta w ograniczonym zakresie. Artykuł ma na celu przybliżenie stosowania egze-

1 Liczba zgłoszonych w 2016 r. w trybie krajowym wynalazków, wzorów użytkowych, znaków towarowych i wzorów przemysłowych wyniosła 21.375 szt., zaś liczba praw wyłącznych na przedmiotach własności przemysłowej pozostającej w mocy w Polsce na dzień 31 grudnia 2016 r. wyniosła 305.143 szt. (źródło: Urząd Patentowy Rzeczypospolitej Polskiej, Raport roczny, Warszawa 2016, s. 11), zaś stan zaległości budżetu Państwa na 31 grudnia 2016 r. wyniósł 85.455.095 tys. zł (źródło: Ministerstwo Finansów, Informacja o kształtowaniu się zaległości budżetowych wg stanu na 31 grudnia $2016 r$.). 
kucji uregulowanej w art. 96a-96i ustawy o postępowaniu egzekucyjnym w administracji. Celem niniejszego opracowania jest przedstawienie jednego ze środków egzekucyjnych - egzekucji z autorskich praw majątkowych i praw pokrewnych oraz praw własności przemysłowej. Środka egzekucyjnego, który ze względu na swoją złożoność sprawia organom egzekucyjnym trudności w jego stosowaniu. W opracowaniu dokonano przeglądu dorobku literatury oraz przepisów z zakresu administracyjnego postępowania egzekucyjnego.

Słowa kluczowe: egzekucja administracyjna; autorskie prawa majątkowe i prawa pokrewne; prawa własności intelektualnej.

Abstract. Enforcement of copyrights and related rights, and industrial property rights is one of enforcement measures in the administrative enforcement proceedings relating to monetary claims. There is a great number of registered industrial property rights and tax arrears ${ }^{2}$. However, the administrative enforcement body takes advantage of copyrights and related rights and industrial property rights in a limited scope. The paper will introduce the application of enforcement measures subject to article 96a-96i of the Act on enforcement proceedings in administration. Its purpose is to present one of the enforcement measures, namely the enforcement of copyrights and related rights, and industrial property rights, which is an enforcement measure which enforcement bodies find difficult to apply, owing to its complexity. The paper reviews the subject literature and regulations on the administrative enforcement proceedings.

Keywords: administrative enforcement; copyrights and related rights; intellectual property rights.

\section{Wprowadzenie}

W ustawie z dnia 17 czerwca 1966 r. o postępowaniu egzekucyjnym $\mathrm{w}$ administracji ${ }^{3} \mathrm{w}$ sposób szczególny unormowano egzekucję $\mathrm{z}$ autor-

2 The total number of inventions, utility models, trademarks and industrial designs registered in 2016 totalled 21,375, the number of exclusive rights to industrial property in force as of 31 December 2016 reached 305,143 (source: Patent Office of the Republic of Poland, Raport Roczny, Warsaw 2016, p. 11), and the stock of state budget arrears as of 31 December 2016 was 85,455,095 thousand zlotys (source: Ministry of Finance, Information on the shape of budget arrears as of 31 December 2016).

$3 \quad$ Tekst jedn. Dz.U. z 2017 r. poz. 1201 ze zm., dalej: u.p.e.a. 
skich praw majątkowych i praw pokrewnych oraz z praw własności przemysłowej, a więc praw zaliczanych do tzw. dóbr niematerialnych o charakterze intelektualnym (nazywanych inaczej prawami własności intelektualnej). Pojęcie to obejmuje zarówno prawa autorskie, jak i prawa własności intelektualnej ${ }^{4}$ (wskazać należy, iż termin ten nie występuje w u.p.e.a.). Ustawodawca w art. $96 \mathrm{~g} \S 1$ u.p.e.a. wymienił prawa podlegające trybowi egzekucji z autorskich praw majątkowych i praw pokrewnych oraz z praw własności przemysłowej ${ }^{5}$. Należy przyjąć, że jest to katalog zamknięty, co nie oznacza, że tryb ten może jedynie dotyczyć praw wymienionych enumeratywnie w tym przepisie ${ }^{6}$.

W przepisach art. 1a pkt 12 lit. a) i art. 96g u.p.e.a nie występuje wprost termin prawo własności intelektualnej w żadnym ze wskazanych znaczeń. Wymienione w omawianych przepisach kategorie praw: majątkowe prawa autorskie, prawa pokrewne czy prawa własności intelektualnej stanowią jednak desygnaty tego terminu, ujmowanego podmiotowo. Ujęte w u.p.e.a kategorie praw nie wyczerpują w całości zbioru praw własności intelektualnej, które reguluje polskie ustawodawstwo. Nie obejmuje one prawa z nieautorskiej bazy danych, o którym mowa w art. 6 ustawy z dnia 27 lipca 2001 r. o ochronie baz danych ${ }^{7}$, ponieważ nie jest one ani prawem autorskim, ani prawem pokrewnym, ani prawem własności przemysłowej. Stanowi jednak podmiotowe prawo własności intelektualnej.

Zgodnie $\mathrm{z}$ powołanymi przepisami przedmiotem zastosowanego środka egzekucyjnego, czyli zinstytucjonalizowanej formy przymusu państwowego stosowanego przez powołane organy przewidziane w u.p.e.a. i służącego do doprowadzenia wykonania przez zobowiązanego obowiąz-

4 Zob. A. Jakubecki, Postępowanie zabezpieczające w sprawach z zakresu prawa własności intelektualnej, Kraków 2002, s. 17-22 oraz S. Gronowski, Prawo własności przemysłowej. Zagadnienia ogólne i proceduralne, Warszawa 2002, s. 10-11.

5 Przepisy art. 96g-96i u.p.e.a. regulujące egzekucję z autorskich praw majątkowych i praw pokrewnych oraz z prawa własności przemysłowej obowiązują od 30 listopada 2001 r. i zostały wprowadzone ustawą z dnia 6 września 2001 r. o zmianie ustawy o postępowaniu egzekucyjnym w administracji oraz niektórych innych ustaw (Dz.U. nr 125, poz. 1368).

$6 \quad$ R. Hauser, A. Skoczylas (red.), Postępowanie egzekucyjne w administracji. Komentarz, Warszawa 2011, s. 442.

7 Dz.U. Nr 128, poz. 1402 ze zm. 
ków wynikających ze stosunków administracyjno-prawnych oraz innych obowiązków podanych egzekucji administracyjnej, są autorskie prawa majątkowe oraz prawa pokrewne oraz prawa własności przemysłowej. Prawa te mogą mieć zdolność egzekucyjną, czyli mogą stanowić przedmiot, z którego można prowadzić egzekucję administracyjną. Regulacje prawne dotyczące autorskich praw majątkowych i praw pokrewnych zawarte są w ustawie o prawie autorskim i prawach pokrewnych ${ }^{8} . \mathrm{Z}$ kolei prawa własności przemysłowej uregulowane zostały w ustawie prawo własności przemysłowej ${ }^{9}$. Wyliczenie praw własności intelektualnej, z których możliwe jest przeprowadzenie egzekucji, jest wyczerpujące, czyli zastosowanie środka egzekucyjnego ograniczone jest do: autorskiego prawa majątkowego i praw pokrewnych, patentu, prawa ochronnego na wzór użytkowy, prawa z rejestracji wzoru zdobniczego, prawa z rejestracji znaku towarowego, prawa do używania znaku towarowego powszechnie znanego niezarejestrowanego, prawa $\mathrm{z}$ rejestracji topografii układu scalonego, prawa do projektu racjonalizatorskiego oraz korzyści z tych praw.

Wynalazek podlegający opatentowaniu to nowe rozwiązanie o charakterze technicznym, posiadające poziom wynalazczy (tzn. niewynikające w sposób oczywisty ze stanu techniki) i nadające się do przemysłowego stosowania. Wynalazek chroniony jest patentem. Treścią patentu jest prawo wyłącznego korzystania z wynalazku na określonym terytorium w sposób zarobkowy lub zawodowy, przez okres i na warunkach określonych w krajowej ustawie patentowej lub konwencji międzynarodowej. Czas trwania patentu wynosi 20 lat od daty dokonania zgłoszenia wynalazku we właściwym organie krajowym lub organizacji międzynarodowej, np. Europejskim Urzędzie Patentowym.

W przepisach art. 96g § 1 u.p.e.a. nie wyszczególniono prawa z rejestracji wzoru przemysłowego oraz prawa $\mathrm{z}$ rejestracji oznaczenia geograficznego określonych odpowiednio w art. 102 i 184 p.w.p., prawa o ochronie baz danych, o których mowa w art. 6 ustawy o ochronie baz

8 Ustawa z dnia 4 lutego 1994 r. o prawie autorskim i prawach pokrewnych (tekst jedn. Dz.U. z 2017 r., poz. 880, dalej: pr. aut.).

9 Ustawa z dnia 30 czerwca 2000 r. Prawo własności przemysłowej (tekst jedn. Dz.U. z 2017 r., poz. 776, dalej: p.w.p.). 
danych. Prawa te uznać należy za prawa własności intelektualnej, które nie podlegają egzekucji administracyjnej w trybie przepisów art. 96g u.p.e.a., co nie oznacza, że są one pozbawione zdolności egzekucyjnej. Przeprowadzenie egzekucji administracyjnej z tych praw możliwe jest jednak na podstawie przepisów art. 96l-96m u.p.e.a., tj. egzekucji z pozostałych praw majątkowych $^{10}$.

Wzór użytkowy to nowe i użyteczne rozwiązanie o charakterze technicznym dotyczące kształtu, budowy lub zestawienia przedmiotu o trwałej postaci. Wzór użytkowy chroniony jest prawem ochronnym. Stanowi odrębny przedmiot ochrony własności przemysłowej, który dotyczy tylko przedmiotu materialnego o trwałej postaci, określonego poprzez cechy techniczne przedmiotu, przejawiające się w ukształtowaniu przestrzennym (kształcie) i/lub budowie (konstrukcji) danego przedmiotu jako całości bądź zestawienia elementów) niepołączonych ze sobą konstrukcyjnie), również określonych co do ukształtowania przestrzennego ${ }^{11}$. Prawo wyłączne na wzory użytkowe udzielane jest w Polsce przez Urząd Patentowy Rzeczypospolitej Polskiej, którego treścią jest prawo wyłącznego korzystania z wzoru użytkowego w sposób zawodowy lub zarobkowy na terytorium całego kraju. Czas trwania prawa ochronnego z korzystania ze wzoru użytkowego w sposób zawodowy lub zarobkowy wynosi 10 lat od daty zgłoszenia wzoru w Urzędzie Patentowym.

Wzór przemysłowy to nowa, oryginalna nadająca się do wielokrotnego odtwarzania postać wytworu, przejawiająca się w szczególności w jego kształcie, właściwości powierzchni, barwie, rysunku lub ornamencie. Wzór przemysłowy chroniony jest prawem z rejestracji. Prawo wyłączne z rejestracji jest udzielane w Polsce przez Urząd Patentowy na wzory przemysłowe, którego treścią jest prawo wyłącznego korzystania wzoru przemysłowego w sposób zawodowy lub zarobkowy na terytorium całego kraju. Czas trwania prawa z rejestracji wynosi 25 lat od daty dokonania zgłoszenia w Urzędzie Patentowym. Decyzja o udzieleniu prawa

10 Zob. M. Faryna, Komentarz do art. 96 g u.p.e.a., [w:] D.R. Kijowski (red.), Ustawa o postępowaniu egzekucyjnym w administracji. Komentarz, Warszawa 2015, s. 997.

11 Wyrok WSA w Warszawie z 9 listopada 2006 r., VI SA/Wa 1613/2006, LexPolonica nr 1547059. 
ochronnego na wzór użytkowy jest wydawana przez Urząd Patentowy RP (art. 52 ust $1 \mathrm{w}$ zw. $\mathrm{z}$ art. 100 ust.1 p.w.p.).

Poza wymienionymi prawami wyłącznymi katalog praw, do których mają zastosowanie przepisy art. 96g u.p.e.a., zawierają prawo, które nie ma charakteru prawa wyłącznego i zostało określone jako „prawo do projektu racjonalizatorskiego”. Przez pojęcie projektu racjonalizatorskiego w rozumieniu art. 7 p.w.p. rozumie się każde rozwiązanie nadające się do wykorzystania, niebędące wynalazkiem, wzorem użytkowym, wzorem przemysłowym lub topografią układu scalonego, rozwiązania nadającego się do wykorzystania w toku prowadzenia przedsiębiorstwa, o ile mają charakter innowacyjny. Przyjąć można, iż projekt racjonalizatorski pod rządami ustawy to innowacyjne rozwiązanie udoskonalające procesy produkcji, zawierające mniejsze natężenie „myśli twórczej” niż inne projekty wynalazcze, którego wyodrębnienie jest w pełni zależne od unormowań regulaminu racjonalizacji. Tak rozumiane pojęcie projektu racjonalizatorskiego uznać należy za dobro intelektualne.

W kontekście przedmiotowej regulacji zasadne byłoby przyjąć, iż prawo do projektu racjonalizatorskiego nabywa nie twórca, ale przedsiębiorca, który nabywa to prawo od twórcy na mocy ustanowionego przez siebie regulaminu i jako prawo przedsiębiorcy do wykorzystania przyjętego projektu racjonalizatorskiego $\mathrm{w}$ toku prowadzenia przedsiębiorstwa. Majątkowe prawo do projektu racjonalizatorskiego raczej nie będzie miało charakteru prawa wyłącznego, ale stanowić może majątkowe roszczenie o charakterze cywilnym ${ }^{12}$. Przyjęcie takiego stanowiska nie wyłącza możliwości zastosowania środka egzekucyjnego do takiego prawa majątkowego, ale już na podstawie art. 89 u.p.e.a. i następnych lub art. 961 ust. 2 u.p.e.a. i następnych, a ewentualne odstąpienie od zastosowania egzekucji w trybie art. 96g u.p.e.a. Wskazać jednak należy, iż przepisy o zastosowaniu środka egzekucyjnego w trybie art. 961 u.p.e.a. mają zastosowanie w egzekucji do takich praw majątkowych, których wykonywanie uza-

12 Sąd Najwyższy w wyroku z 9 stycznia 2001 r., I PKN 493/00 (OSNP 2002, nr 17, poz. 407) uznał, iż „Właścicielem praw autorskich do programu komputerowego wykonanego w ramach obowiązków pracowniczych jest pracodawca, chyba że w umowie o pracę lub umowie cywilnoprawnym strony postanowią inaczej”. 
leżnione jest od posiadania dokumentu, albo są to prawa tego rodzaju, że jest oznaczony podmiot obciążony względem zobowiązanego.

W sytuacji pracowniczego regulaminu racjonalizatorskiego, w którym przewidziano twórcy projektu racjonalizatorskiego wynagrodzenie pieniężne, raczej powinny mieć zastosowanie przepisy dotyczące egzekucji z wynagrodzenia (art. 72 u.p.e.a) lub egzekucji z innych wierzytelności pieniężnych (art. 89 u.p.e.a.).

Z kolei przedmiotem zastosowania środka egzekucyjnego przewidzianego w art. 89 § 2 u.p.e.a, tj. egzekucji z innych wierzytelności pieniężnych uzasadnione jest istnienie wierzytelności pieniężnej. Ustawodawca jednak wprowadził wyjątek, który rozszerza możliwości stosowania tego środka także na wierzytelności przyszłe. W doktrynie prezentowany jest pogląd zmierzający raczej w kierunku rozszerzającej wykładni pojęć, jakie zostały użyte w art. $89 \S 2$ u.p.e.a. Wskazuje się, że dla zastosowania tego przepisu nie ma znaczenia, czy dostawa, robota czy usługa, z tytułu której powstaje wierzytelność, jest świadczona na podstawie umowy regulowanej przepisami kodeksu cywilnego, a więc umową nazwaną, czy też następuje na podstawie umowy nienazwanej, tj. zaliczenie jako przedmiotu egzekucji w tym trybie również wierzytelności o zapłatę za świadczenia niepieniężne, spełnione w ramach umów dostawy, umów o dzieło, umów o roboty budowlane, umów zlecenia, jak również innych wszelkiego rodzaju umów nazwanych i umów nienazwanych. W doktrynie prezentowany jest pogląd zmierzający raczej w kierunku rozszerzającej wykładni pojęć, które zostały użyte w tym przepisie ${ }^{13}$.

Zgodnie z ustawą p.w.p. znakiem towarowym może być każde oznaczenie przedstawione w sposób graficzny lub takie, które da się w sposób graficzny wyrazić, jeżeli oznaczenie takie nadaje się do odróżnienia w obrocie towarowym jednego przedsiębiorstwa od tego samego rodzaju towarów innych przedsiębiorstw. Znakiem towarowym może być w szczególności wyraz, rysunek, ornament, kompozycja kolorystyczna, forma przestrzenna, w tym forma towaru lub opakowania, a także melodia

13 Zob. P. Rączka, Egzekucja z autorskich praw majqtkowych i praw pokrewnych oraz z praw własności przemysłowej, [w:] T. Jędrzejewski, M. Masternak, P. Rączka, Administracyjne postępowanie egzekucyjne, Toruń 2006, s. 176. 
lub inny sygnał dźwiękowy. Na znak towarowy udziela się prawa ochronnego, którego czas trwania wynosi 10 lat od daty dokonania zgłoszenia w Urzędzie Patentowym i które może być przedłużone na kolejne okresy 10-letnie. Przy przeprowadzeniu egzekucji ze znaków towarowych należy jednak wziąć pod uwagę, że prawo ochronne na znak towarowy, mimo iż jest zbywalne, to jednak jego przeniesienie bez przeniesienia przedsiębiorstwa może nastąpić tylko wtedy, gdy nie występuje niebezpieczeństwo wprowadzenia odbiorców w błąd co do rzeczywistego pochodzenia towarów ani ich cech lub jakości ${ }^{14}$.

Z kolei oznaczenie geograficzne to oznaczenia słowne odnoszące się bezpośrednio lub pośrednio do nazwy, miejsca, miejscowości, regionu lub kraju (terenu), które identyfikują towar jako pochodzący z tego terenu, jeżeli określona jakość, dobra opinia lub inne cechy towaru są przypisywane przede wszystkim pochodzeniu geograficznemu tego towaru (art. 174 ust 1 p.w.p.). Rejestracja oznaczeń geograficznych jest wynikiem dobrowolnej inicjatywy zainteresowanego podmiotu ${ }^{15}$. Prawo ochronne z rejestracji na znak geograficzny jest udzielane bezterminowo.

W systemie polskiego prawa również wyłączne prawo ochrony roślin jest prawem z zakresu praw wyłącznych na dobrach niematerialnych, a zatem prawem z zakresu tzw. własności intelektualnej oraz prawo ochronny produktu leczniczego ma maksymalny okres ochronny do 5 lat, w przypadku produktów leczniczych pediatrycznych do 5 lat i 6 miesięcy. Prawo ochronne dla produktów leczniczych oraz produktów ochrony roślin jest odrębnym od patentu tytułem ochronnym. W prawie polskim co do rejestracji odmian roślin obowiązują dwie ustawy, a mianowicie ustawa z dnia 9 listopada 2012 r. o nasiennictwie ${ }^{16}$ oraz ustawa z dnia 26 czerwca 2003 r. o ochronie prawnej odmian roślin ${ }^{17}$. Ochrona prawna odmian roślin jest wyłączona z prawa własności przemysłowej, odmiany nie są patentowane na poziomie krajowym ani europejskim. Prawo wy-

\footnotetext{
14 Wyrok Trybunału Konstytucyjnego z 21 marca 2001 r., K. 24/00 (OTK 2001 Nr 3, poz. 51).

J. Sieńczyło-Chlabicz (red.), Prawo własności intelektualnej, Warszawa 2009, s. 409.

Tekst jedn. Dz.U. z 2017 r., poz. 633.

Tekst jedn. Dz.U. z 2017 r., poz. 843.
} 
łączne do odmiany rośliny uzyskuje się w Polsce w Centralnym Ośrodku Roślin Uprawnych decyzją dyrektora. Można również uzyskać je w europejskim urzędzie o nazwie Community Plant Variety Office (CPVO), wówczas jest skuteczne na całym terytorium Unii Europejskiej. Jednakże odmiana nie może być równocześnie przedmiotem ochrony na poziomie krajowym i wspólnotowym. Ochrona krajowa ulega zawieszeniu, jeżeli hodowca uzyska prawo wspólnotowe, natomiast uzyskane prawo wspólnotowego do odmiany umożliwia składanie wniosku o uzyskanie ochrony krajowej. Prawo wyłączne odnosi się przede wszystkim do wytwarzania i rozmnażania, oferowania do sprzedaży i sprzedaż lub inne formy zbywania materiału siewnego odmiany chronionej. Prawo hodowcy objęło nim również materiał ze zbioru, czyli ten, który posiadacz gruntu rolnego zebrał i użył jako materiał siewny (mimo że wcześniej zapłacił hodowcy za materiał siewny i wysiał na posiadanym przez siebie gruncie).

\section{Charakter i zakres praw własności intelektualnej}

Światowa Organizacja Własności Intelektualnej (ang. World Intellectual Property Organization, w skrócie WIPO) definiuje pojęcie własności intelektualnej (ang. intellectual property) jako zbiór praw odnoszących się w szczególności do: dzieł literackich, artystycznych i naukowych, interpretacji artystów, interpretatorów oraz wykonań artystów wykonawców, fonogramów i programów radiowych i telewizyjnych, wynalazków we wszystkich dziedzinach działalności ludzkiej, odkryć naukowych, wzorów przemysłowych, znaków towarowych i usługowych, nazw handlowych i oznaczeń handlowych, ochrony przed nieuczciwą konkurencją ${ }^{18}$. Adaptując powyższą definicję do polskich uregulowań prawnych, pod pojęciem własności intelektualnej należy rozumieć prawa związane z działalnością intelektualną w dziedzinie literackiej, artystycznej, naukowej i przemysłowej, obejmujące: prawo autorskie i prawa pokrewne z prawami autor-

18 Zob. Traktat Światowej Organizacji Własności Intelektualnej o prawie autorskim, sporządzony w Genewie 20 grudnia 1996 r. (Dz.U. z 2005 r. Nr 3, poz. 12). 
skimi, prawa do baz danych, prawo własności przemysłowej dotyczące: wynalazków, wzorów użytkowych i wzorów przemysłowych, znaków towarowych, oznaczeń geograficznych i topografii układów scalonych.

Zgodnie z art. 1 pr. aut. przedmiotem prawa autorskiego jest każdy przejaw działalności twórczej o indywidualnym charakterze, ustalony w jakiejkolwiek postaci, niezależnie od wartości, przeznaczenia i sposobu wyrażenia, czyli utwór (dzieło). Utwór jest dobrem niematerialnym, w odróżnieniu od przedmiotu materialnego, jakim jest nośnik, służący utrwaleniu utworu. Do przedmiotów prawa autorskiego ustawa zalicza w szczególności utwory: wyrażone słowem, symbolami matematycznymi, znakami graficznymi (literackie, publicystyczne, naukowe, kartograficzne oraz programy komputerowe), plastyczne, fotograficzne, lutnicze, wzornictwa przemysłowego, architektoniczne, architektoniczno-urbanistyczne i urbanistyczne, muzyczne i słowno-muzyczne, sceniczne, scenicznomuzyczne, choreograficzne, i pantomimiczne, audiowizualne. Własność intelektualna rozumiana jest bądź jako synonim praw autorskich i praw pokrewnych, bądź jako określenie zbiorcze, w skład którego wchodzi własność przemysłowa oraz prawo autorskie i prawa pokrewne ${ }^{19}$.

Zgodnie $\mathrm{z}$ art. 8 ust. 1 pr. aut. prawo autorskie przysługuje $\mathrm{z}$ reguły na rzecz twórcy, którym może być wyłącznie osoba fizyczna, co wynika z samej natury procesu twórczego, bez względu na fakt, czy ta osoba posiada pełną, czy ograniczoną zdolność do czynności prawnych lub nawet jest jej pozbawiona (np. z powodu wieku, np. osoba małoletnia lub ubezwłasnowolniona). Brak pełnej zdolności do czynności prawnych wiąże się jedynie z brakiem możliwości samodzielnego dysponowania prawami autorskimi. Zasadę przysługiwania praw autorskich twórcy należy odpowiednio stosować do współtwórczości, tzn. sytuacji, gdy utwór tworzony jest przez wiele osób. Dopóki twórca nie ujawnił swojego nazwiska, w wykonywaniu prawa autorskiego lub braku możliwości uzyskania od niego odpowiedniego oświadczenia - organ egzekucyjny na potrzeby egzekucji może zwrócić się o uzyskanie takiej informacji w pierwszej

19 M. du Vall, Prawo patentowe, Warszawa 2008, s. 211. 
kolejności do producenta lub wydawcy, a w razie jego braku - do właściwej organizacji zbiorowego zarządzania prawami autorskimi ${ }^{20}$.

Ustawa o prawie autorskim i prawach pokrewnych wyróżnia autorskie prawa osobiste i autorskie prawa majątkowe. Autorskie prawa osobiste to rodzaj szczególnej więzi, niezbywalnej i niepodlegającej zrzeczeniu się, łączącej twórcę z jego utworem, a wyrażającej się w prawie do: autorstwa utworu, oznaczenia utworu swoim nazwiskiem lub pseudonimem albo do udostępniania go anonimowo, nienaruszalności treści i formy utworu oraz jego rzetelnego wykorzystania, decydowania o pierwszym udostępnieniu utworu publiczności, nadzoru nad sposobem korzystania $\mathrm{z}$ utworu.

Majątkowe prawa autorskie bazują na koncepcji prawa własności z kodeksu cywilnego. Są one cywilnymi prawami podmiotowymi o charakterze bezwzględnym (skuteczne erga omnes). Głównie to ze względu na charakter przedmiotu (dobro niematerialne) są one innym prawem niż własność i mają swe źródło w monopolu przyznanym przez ustawodaw$\mathrm{ce}^{21}$. Są to uprawnienia, których realizacja ma na celu zaspokojenie ekonomicznych interesów właściciela utworu. Celem wprowadzenia praw autorskich majątkowych było zabezpieczenie interesów twórców oraz wydawców. Efektem naruszenia tych właśnie praw są m.in. szkody z tytułu: utraty przez twórców zysków z tytułu rozpowszechniania utworów, straty firm zajmujących się dystrybucją i promocją utworów oraz straty państwa związane z nieodprowadzonymi podatkami.

Autorskie prawa majątkowe obejmują prawo: do korzystania z utworu, rozporządzania utworem na wszystkich polach eksploatacji, wynagrodzenia za korzystanie z utworu. Autorskie prawa majątkowe powstają z reguły na rzecz twórcy. Wyjątek stanowią utwory zborowe, których właścicielem autorskich praw majątkowych jest producent lub wydawca, zaś pracodawca w odniesieniu do programów komputerowych stworzonych przez pracownika w wyniku wykonywania obowiązków ze stosunku pracy w ramach tzw. pierwotnego lub pochodnego ich nabycia ${ }^{22}$. Reguła

20 R. Golat, Prawo autorskie. Komentarz dla praktyków, Gdańsk 2008, s. 34.

21 J. Barta, R. Markiewicz, Prawo autorskie i prawa pokrewne, Warszawa 2008, s. 69.

22 Wyrok SN z 26 czerwca 1998 r., I PKN 196/98 (OSP 1999, Nr 11, poz. 207). 
ta odnosić się będzie również do dzieł stworzonych na zamówienie na podstawie umowy o dzieło lub umowy zlecenia, a także dzieł wykonywanych w ramach konkursu ${ }^{23}$. Autorskie prawa majątkowe wchodzą w skład majątku dysponującego nimi podmiotu, pozostają w związku z prowadzeniem działalności gospodarczej, jak również mogą być przedmiotem aportu (wkładu niepieniężnego) jako prawo majątkowe, jeżeli są zbywalne. Autorskie prawo majątkowe z uwagi na wymierną, możliwą do ustalenia wartość księgową mogą wejść jako aktywa bilansu. Prawa te stanowią majątek osobisty każdego z małżonków i nie wchodzą w skład wspólności majątkowej, podobnie jak prawa pokrewne oraz prawa własności przemysłowej, chyba że małżonkowie umówią się w tym zakresie inaczej ${ }^{24}$.

Prawa autorskie mają charakter terytorialny. Oznacza, to że autorskie prawa osobiste i majątkowe do danego utworu są chronione na podstawie omawianej ustawy jedynie na terytorium danego kraju. Podobnie jak właściciel rzeczy, twórca ma prawo do rozporządzania swoim utworem oraz prawo do korzystania z niego. Przepisy art. 17 prawa autorskiego wymieniają jeszcze prawo do pobierania wynagrodzenia za korzystanie $\mathrm{z}$ utworu.

Majątkowe prawa autorskie można przenieść na inne osoby w drodze dziedziczenia lub na podstawie umowy: o przeniesienie autorskich praw majątkowych (cesja praw) oraz o korzystanie z utworu (licencja). Współautorom utworu przysługuje wspólne majątkowe prawo autorskie. Domniemywa się, że wielkości ich udziałów są równe. Każdy ze współtwórców może jednak żądać określenia ich wielkości przez sąd, który w tej mierze powinien się kierować wkładami pracy twórcy. Przedmiotem wspólności są jedynie prawa majątkowe. Prawa te uznać można, iż mają zdolność egzekucyjną, tzn., że można do tych praw zastosować środek egzekucyjny wymieniony w art. $96 \mathrm{~g}$ u.p.e.a.

Według art. 2 ustawy o ochronie baz danych baza danych oznacza zbiór danych lub jakichkolwiek innych materiałów i elementów groma-

23 Zob. art. 931 § 3 ustawy z dnia 23 kwietnia 1964 r. Kodeks cywilny (tekst jedn. Dz.U. z 2017 r., poz. 459).

24 Zob. art. 33 ust. 10 oraz art. 47 § 1 ustawy z dnia 25 lutego 1964 r. - Kodeks rodzinny i opiekuńczy (tekst jedn. Dz.U. z 2017 r., poz. 682). 
dzonych według określonej systematyki lub metody, indywidualnie dostępnych w jakikolwiek sposób, w tym środkami elektronicznymi, wymagający istotnego co do jakości lub ilości nakładu inwestycyjnego w celu sporządzenia, weryfikacji lub prezentacji jego zawartości. Zgodnie z art. 2 ust.1 pkt 4 ustawy producentem baz danych jest osoba fizyczna, prawna lub jednostka organizacyjna nieposiadająca osobowości prawnej, która ponosi ryzyko nakładu inwestycyjnego przy tworzeniu baz danych. Ustawa przyznaje producentowi prawo (wyłączne i zbywalne) pobierania danych i wtórnego ich wykorzystania w całości lub w istotnej części, co do jakości lub ilości.

Z kolei prawa pokrewne są to prawa do artystycznych wykonań, którymi są w szczególności działania aktorów, recytatorów, dyrygentów, instrumentalistów, wokalistów, tancerzy i mimów oraz innych osób w sposób twórczy przyczyniających się do powstania wykonania. Ponadto do praw pokrewnych zaliczane są: prawa do fonogramów (pierwszego utrwalenia warstwy dźwiękowej wykonania utworu albo innych zjawisk akustycznych) i wideogramów (pierwszego utrwalenia sekwencji ruchomych obrazów z dźwiękiem lub bez, niezależnie od tego, czy stanowi ono utwór audiowizualny), prawa do nadań programów przysługujących organizacji radiowej lub telewizyjnej, prawa do pierwszych wydań oraz wydań naukowych i krytycznych.

W prawie wspólnotowym termin „własność przemysłowa i handlowa” ma autonomiczne znaczenie, wypracowane w orzecznictwie Europejskiego Trybunału Sprawiedliwości dotyczącym art. 36 TfUE $^{25}$. Obejmuje ono patenty, prawa z rejestracji wzorów użytkowych, prawa z rejestracji wzorów przemysłowych, prawa z rejestracji znaków towarowych i znaków powszechnie znanych, prawa do nazw handlowych oraz prawa do nazw pochodzenia i oznaczeń geograficznych, a także prawo autorskie i prawa pokrewne ${ }^{26}$.

25 Wersja skonsolidowana Traktatu o funkcjonowaniu Unii Europejskiej, Dz.Urz. UE z 30 marca 2010 r. nr 2010/C83/01 (dawnej art. 30 TWE).

26 Zob. R. Skubisz (red.), Własność przemysłowa. Orzecznictwo Trybunału Sprawiedliwości Wspólnot Europejskich, Sq̨du Pierwszej Instancji i Urzędu Harmonizacji Rynku Wewnętrznego z komentarzami, Warszawa 2008, s. 105. 
Prawa własności przemysłowej to zespół praw w znaczeniu podmiotowym i przedmiotowym. Prawa własności przemysłowej w znaczeniu podmiotowym oznaczać będzie prawo do dóbr niematerialnych, którymi są: projekty wynalazcze, w tym: wynalazki (nowe w skali światowej rozwiązania, posiadające poziom wynalazczy i nadające się do przemysłowego stosowania), wzory użytkowe (rozwiązania techniczne dotyczące kształtu, budowy lub zestawienia przedmiotu o trwałej postaci, nowe w skali światowej i użyteczne), wzory przemysłowe (nowe i oryginalne postaci wytworu, przejawiające się w szczególności w kształcie, właściwościach powierzchni, barwie, rysunku lub ornamencie, nadające się do wielokrotnego odtwarzania), topografia układu scalonego (oryginalne rozwiązanie polegające na wyrażonym w dowolny sposób przestrzennym rozplanowaniu elementów, z których co najmniej jeden jest aktywny, oraz połączeń między nimi, przy czym pojęcie „układ scalony” oznacza warstwowy wytwór przestrzenny, utworzony w celu spełniania funkcji elektronicznych), projekty racjonalizatorskie (każde rozwiązanie zgłoszone przedsiębiorcy przez twórcę, nadające się do wykorzystania, a niebędące wynalazkiem, wzorem użytkowym, wzorem przemysłowym lub topografią układu scalonego), znaki towarowe (dowolnego rodzaju oznaczenia przedstawione w sposób graficzny lub dające się w ten sposób wyrazić, które mogą służyć do odróżniania w obrocie towarów lub usług określonego przedsiębiorstwa od towarów lub usług tego samego rodzaju innych przedsiębiorstw).

Wiedzę dotyczącą przysługujących danej osobie praw własności przemysłowej organ egzekucyjny może pozyskać z dokumentu świadczącego o posiadaniu przez zobowiązanego jednego z omawianych praw, np. dokumentu stwierdzającego, że rozwiązanie stanowi wynalazek, świadectwa ochronnego na wzór użytkowy, świadectwa rejestracji topografii itp.

\section{Zakres zajęcia prawa własności intelektualnej}

Autorskie prawa majątkowe są skonstruowane jako prawa ograniczone w czasie. Zasadniczą konsekwencją przyjęcia zasady czasowego ograniczenia autorskich praw majątkowych jest to, że autorskie prawo majątko- 
we służące twórcy za jego życia jest wyłączone spod zajęcia. Jeżeli więc będzie ono przeniesione na inny podmiot (następcę prawnego), może być przedmiotem egzekucji administracyjnej. Ograniczenia związane z osobą twórcy, o których mowa z art. 96g § 3 pkt 1 u.p.e.a., nie obejmują wymagalnych wierzytelności z tytułu majątkowych praw autorskich, np. honorarium autorskiego przysługującego po upływie terminu w umowie zawartej przez twórcę ${ }^{27}$.

Przepis art. 96g § 3 pkt 1 u.p.e.a. swoim zakresem wykracza poza reżim prawny przewidziany w art. 96g i n. u.p.e.a. Nie jest więc dopuszczalne prowadzenie egzekucji z autorskich praw majątkowych służących twórcy za życia łącznie z korzyściami z tych praw zarówno na podstawie art. 96 i n., jak i na podstawie art. 72 i n., art. 89 i n. albo art. 961 i n. u.p.e.a., chyba że są to majątkowe roszczenia autorskie, które są już wymagalne $^{28}$. W razie śmierci twórcy $\mathrm{w}$ toku prowadzonego postępowania egzekucyjnego na mocy art. 56 § 1 ust 2 u.p.e.a. organ egzekucyjny zawiesza postępowanie egzekucyjne do momentu, gdy zostanie on zawiadomiony przez wierzyciela o ustaniu przyczyn według przepisów prawa cywilnego - spadkobierców zmarłego, na których przeszedł egzekwowany obowiązek.

Czas ochrony autorskiego praw majątkowych z zasady wynosi całe życie autora plus 70 lat od jego śmierci. W przypadku przedmiotów praw pokrewnych wynosi od 25 do 50 lat $^{29}$. Odstępstwem od wskazanej zasady jest instytucja domaine public payant, przewidująca obowiązek dokonywania zapłaty pewnych kwot na Fundusz Promocji Twórczości ${ }^{30}$.

Prawa autorskiego nie można sprowadzać jedynie do interesów o charakterze majątkowym, bowiem istnieje istotna grupa godnych ochrony interesów niemajątkowych (pozaekonomicznych) twórcy. Przysługujące uprawnienia osobiste mają służyć ochronie szczególnej więzi twórcy

M. Faryna, Komentarz do art. $96 \mathrm{~g}$ u.p.e.a..., s. 983.

28 W. Włodarczyk, Egzekucja administracyjna z praw własności intelektualnej, [w:] J. Niczyporuk, S. Fundowicz, J. Radwanowicz (red.), System egzekucji administracyjnej, Warszawa 2004, s. 400.

29 J. Sieńczyło-Chlabicz (red.), Prawo..., s. 35.

30 E. Traple [w:] J. Barta (red.), System Prawa Prywatnego. Prawo autorskie, t. 13, Warszawa 2007, s. 201. 
z utworem i zabezpieczać nie tylko pozycję twórcy jako autora dzieła, lecz również piętna, jakie jego niepowtarzalna osobowość odcisnęła na dziele. Stąd do autorskich uprawnień osobistych zalicza się zarówno prawo do autorstwa w jego aspekcie negatywnym (możliwości domagania się przez twórcę, aby respektowano jego autorstwo) i pozytywnym (wyboru sposobu oznaczenia utworu jego nazwiskiem, pseudonimem czy udostępnienia anonimowo), jak i prawo do integralności utworu służące zabezpieczenia tej postaci dzieła, jaką nadał mu twórca, a także wiele innych zbliżonych uprawnieńn ${ }^{31}$.

Ustawodawca ochronę praw osobistych twórcy w postępowaniu egzekucyjnym zawarł w przepisie art. 96g § 3 u.p.e.a., w którym wyłącza spod zajęcia egzekucyjnego autorskie prawo majątkowe służące twórcy za jego życia, zezwalając jednocześnie na dokonanie zajęcia wymagalnych wierzytelności z tytułu praw autorskich przysługujących autorowi, prawo do utworu nieopublikowanego, jeżeli spadkobiercy sprzeciwiają się egzekucji z tego prawa i sprzeciw ten jest zgodny z ujawnioną wolą twórcy nierozpowszechniania utworu oraz na patent i prawo ochronne ma wzór użytkowy o charakterze tajnym.

Wbrew regulacjom zawartym w art. 96g § 1 pkt 8 u.p.e.a. nie jest możliwe zajęcie prawa do projektu racjonalizatorskiego oraz korzyści z tego prawa. Prawo do projektu racjonalizatorskiego nie podlega rejestracji w Urzędzie Patentowym RP, a więc jest niemożliwe dokonanie zajęcia prawa i korzyści z tego prawa poprzez przesłanie zawiadomienia o zajęciu do Urzędu Patentowego. Zajęcie projektu racjonalizatorskiego oraz korzyści z tego prawa następuje poprzez wpisanie tych praw do protokołu zajęcia i podpisanie protokołu przez poborcę skarbowego, a także zobowiązanego lub świadków - ten sposób dokonania zajęcia dotyczy wszystkich praw podlegających egzekucji w tym trybie ${ }^{32}$.

Wbrew nazwie autorskie prawa osobiste nie mają całkowicie niemajątkowego charakteru, podobnie jak autorskie prawa majątkowe nie są

31 Szerzej: J. Barta, M. Czajkowska-Dąbrowska, Z. Ćwiąkalski, R. Markiewicz, E. Traple, Prawa autorskie i prawa pokrewne. Komentarz, Kraków 2005, s. 227.

32 Zob. P. Rączka, Egzekucja z autorskich praw..., s. 198. 
czysto majątkowe ${ }^{33}$. Jest to pośrednio skutkiem okoliczności, że w ramach społeczeństwa informacyjnego zwiększa się „konsumpcja” wszelkiego rodzaju wytworów intelektualnych, których coraz większa część z nich ma charakter czysto użytkowy. Stąd też brak potrzeby rozbudowywania katalogu autorskich praw osobistych. Przeciwnie - często odbierane są one jako element utrudniający obrót uprawnieniami majątkowymi ${ }^{34}$. Zasygnalizowane procesy być może mogą mieć w niedługiej przyszłości na odejście ochrony praw autorskich przewidzianych art. 96g § 3 u.p.e.a.

Przepisy art. 96g § 3 pkt 3 u.p.e.a wyłączają spod reżimu egzekucyjnego „patent i prawo ochronne na wzór użytkowy o charakterze tajnym”. Wyłączenie te postrzegać należy jako błąd legislacyjny. Wskazać należy, iż nie ma patentów i praw ochronnych na wzory użytkowe, które mają charakter tajny. Zgłoszenia wynalazku tajnego w Urzędzie Patentowym można dokonać tylko w celu zastrzeżenia pierwszeństwa do uzyskania patentu $^{35}$.

\section{Postępowanie wykonawcze w zakresie zastosowania egzekucji z praw własności intelektualnej}

Przedmiotem zajęcia dokonywanego na podstawie art. 96g u.p.e.a. jest jedno z praw należących do kategorii tzw. praw własności intelektualnej oraz korzyści wynikające z tego prawa. Zajęcie prawa własności przemysłowej, o którym mowa w $\S 1$ art. 96g u.p.e.a., poza prawem do używania znaku towarowego powszechnie znanego niezarejstrowanego może nastąpić poprzez wpisanie tego prawa oraz korzyści z tego prawa do protokołu zajęcia i podpisanie protokołu przez poborcę skarbowego, a także zobowiązanego lub świadków albo doręczenie Urzędowi Patentowemu RP

33 J. Barta, R. Markiewicz: Prawo autorskie, Warszawa 2010, s. 19.

34 A. Wojciechowska, Osobiste prawa autorskie w stronę zmiany paradygmatu, [w:] J. Barta, R. Markiewicz, Prawo autorskie a postęp techniczny, Kraków 1999, s. 155.

35 W Polsce patenty udzielane są przez Urząd Patentowy Rzeczypospolitej Polskiej, a po przystąpieniu Polski do Europejskiej Organizacji Patentowej od 1 marca 2004 r., również przez jej organ wykonawczy, którym jest Europejski Urząd Patentowy z siedzibą w Monachium, jeżeli w zgłoszeniu patentu europejskiego wskazana została Polska. 
zawiadomienia o zajęciu prawa. O skuteczności chwili zajęcia decyduje czynność wcześniejsza. Dla określenia chwili zajęcia decydujące jest, która z tych czynności zajęcia była wcześniejsza.

Za dyskusyjne można uznać zawarte w § 2 art. 96g u.p.e.a. stwierdzenie, iż o zajęciu prawa własności intelektualnej decyduje „przesłanie zawiadomienia o zajęciu” jako okoliczność, w wyniku której następuje zajęcie tych praw, niemniej do oceny skuteczności zajęcia istotna będzie data doręczenia zawiadomienia Urzędowi Patentowemu RP (art. 96g § 4 i art. 96h § 2 u.p.e.a.). W trybie art. 96g § 1 u.p.e.a. możliwe będzie przez organ egzekucyjny zajęcie wymienionych praw własności intelektualnej, jak też korzyści z tego prawa. Użycie w omawianym przepisie spójnika „oraz” pozwala na wykładnię dopuszczającą zajęcie praw własności intelektualnej jak też zajęcie tylko samych korzyści ${ }^{36}$. Według W. Włodarczyka w trybie art. 96g u.p.e.a. nie jest możliwe dokonanie zajęcia samego świadczenia będącego korzyścią ${ }^{37}$. Pogląd ten uznać należy za nietrafny, gdyż prawa majątkowe twórcy mogą nie przysługiwać, a korzyści nadal będą przy nim pozostawać.

Do czynności wykonawczych sensu stricte należy zaliczyć stosowanie środków egzekucyjnych. Środki egzekucyjne są tak skonstruowane, aby prowadziły bezpośrednio do realizacji obowiązku o charakterze publicznoprawnym. Środki egzekucyjne to zinstytucjonalizowane formy przymusu państwowego stosowane przez powołane organy przewidziane w ustawie i służące do doprowadzenia do wykonania przez zobowiązanych obowiązków wynikających ze stosunków administracyjno-prawnych oraz innych obowiązków poddanych egzekucji administracyjnej i stosowanych według ściśle określonej procedury ${ }^{38}$. Kolejność, w jakiej ustawa wylicza środki egzekucji, ma znaczenie w przypadku egzekucji należności pieniężnych, są one bowiem uszeregowane od najłagodniejszego do najbardziej dolegliwego (art. 1a pkt 12 lit. a u.p.e.a.). Powinny być stosowa-

36 S. Wronkowska, M. Zieliński, Problemy i zasady redagowania tekstów prawnych, Warszawa 1993, s. 150.

37 W. Włodarczyk, Egzekucja administracyjna..., s. 399

38 Por. E. Bojanowski, Wykonanie zastępcze w egzekucji administracyjnej, Warszawa 1975, s. 35. 
ne w takiej kolejności - zgodnie z zasadą stosowania najłagodniejszego środka, prowadząc bezpośrednio do wykonania obowiązku ${ }^{39}$. W obecnym stanie prawnym uznać należałoby za aktualną tezę, że dokonując wyboru między kilkoma środkami egzekucyjnymi, organ egzekucyjny powinien uwzględnić rodzaj środków, jakie ma do dyspozycji wykonania tego obowiązku, oraz okoliczności faktyczne danej sprawy ${ }^{40}$.

Organ egzekucyjny, dokonując zajęcia prawa własności intelektualnej, obowiązany jest dokonać w protokole zajęcia opisu tego prawa, tj. wskazania rodzaju zajętego prawa oraz dokumentu, o ile to jest możliwe, potwierdzającego udzielenie tego prawa, np. dokumentu patentowego obejmującego: opis wynalazku, zastrzeżenia patentowe, rysunki, zaś częścią składową świadectwa ochronnego jest opis ochronny wzoru użytkowego obejmujący opis tego wzoru, zastrzeżenia ochronne i rysunki (art. 99 p.w.p.). W protokole zajęcia prawa własności intelektualnej zobowiązany ma prawo wnieść zastrzeżenia (oświadczenie), np. co do tego, że zajęte autorskie prawo majątkowe nie jest prawem służącym twórcy za jego życia.

Poborca skarbowy w protokole zajęcia zamieszcza opis zajętych praw i - jeżeli jest to możliwe - wartość szacunkową zajętych praw (art. 96h § 1 u.p.e.a.) ${ }^{41}$. Jeżeli oszacowanie przez poborcę skarbowego wartości zajętych praw nie jest możliwe lub zajęcie jest dokonane przez doręczenie Urzędowi Patentowemu RP zawiadomienia o zajęciu, organ egzekucyjny zwraca się do biegłego skarbowego o oszacowanie wartości tych praw (art. 96h § 3 u.p.e.a.). Na oszacowanie dokonane przez poborcę skarbowego zobowiązanemu przysługuje prawo wniesienia do organu egzekucyjnego zarzutu - w terminie 7 dni od dnia zajęcia. Podmiotem legitymowanym do wniesienia tego zarzutu na oszacowanie zajętego prawa jest

39 Wyrok WSA w Kielcach z dnia 29 stycznia 2008 r. II SA/Ke 683/07 (LEX nr 471275).

40 W. Grześkiewicz, Komentarz do art. 1a) u.p.e.a., [w:] D.R. Kijowski (red.), Ustawa o postępowaniu egzekucyjnym w administracji. Komentarz, Warszawa 2015, s. 71.

41 Wzór protokołu o zajęciu autorskiego prawa majątkowego i prawa pokrewnego lub prawa własności przemysłowej/ zawiadomienie o zajęciu prawa własności przemysłowej zamieszczony został w załączniku nr 8 rozporządzenia Ministra Finansów z dnia 22 sierpnia 2016 r. w sprawie wzorów dokumentów stosowanych w egzekucji należności pieniężnych (Dz.U., poz.1339). 
zobowiązany. Ponadto należy zwrócić uwagę, iż zarzut w sprawie oszacowania jest środkiem niedewolutywnym - jest wnoszony do organu prowadzącego postępowanie, który jest również kompetentny do rozpatrzenia zarzutu. W przypadku nieuwzględnienia zarzutu zobowiązanego organ egzekucyjny zwraca się do biegłego skarbowego o oznaczenie wartości zajętych praw (art. 96h § 3 u.p.e.a.). Zadaniem biegłego jest zatem udzielenie organowi egzekucyjnemu specjalnych wiadomości niezbędnych do prowadzenia postępowania oraz rozstrzygnięcia sprawy ${ }^{42}$.

Do zajęcia praw własności intelektualnej może dojść w związku z przeszukaniem odzieży na zobowiązanym lub osobie trzeciej albo przeszukaniem lokalu, pomieszczenia, schowka, toreb, waliz itp. W przypadku znalezienia dokumentu świadczącego o posiadaniu przez zobowiązanego jednego z praw własności intelektualnej, np. świadectwa ochronnego, świadectwa rejestracji, świadectwa rejestracji topografii, poborca skarbowy powinien przystąpić do zajęcia tego prawa. Odebranie tych dokumentów nie jest koniecznym warunkiem zajęcia prawa, ponieważ wykonanie zajętego prawa nie jest uzależnione od posiadania tych dokumentów ${ }^{43}$.

Organ egzekucyjny po dokonaniu zajęcia prawa własności intelektualnej oraz korzyści z tego prawa jest obowiązany doręczyć zobowiązanemu odpis protokołu zajęcia wraz $\mathrm{z}$ odpisem tytułu wykonawczego, o ile wcześniej nie został on doręczony, oraz zawiadomić zobowiązanego, że nie wolno mu rozporządzać zajętymi prawami. Zajęcie prawa należącego do katalogu praw własności intelektualnej oraz korzyści $\mathrm{z}$ tego prawa skutkuje tym, że organ egzekucyjny nabywa prawa do rozporządzania zajętym prawem $\mathrm{w}$ zakresie niezbędnym do wykonania obowiązku objętego tytułem wykonawczym (art. 1a pkt 18 u.p.e.a.), w tym praw zobowiązanego, przez które będziemy rozumieć wszystkie postacie czynności prawnych podmiotu autorskich praw majątkowych, na podstawie których inny podmiot uzyskuje na określonych warunkach

42 M. Masternak, Biegły w postępowaniu podatkowym, „Kwartalnik Prawa Publicznego” 2001, nr 2, wersja on-line, http://lex.pl/czasopisma.

43 Zob. P. Przybysz, Postępowanie egzekucyjne w administracji. Komentarz, Warszawa 2009, s. 349; D. Jankowiak, Ustawa o postępowaniu egzekucyjnym w administracji, Komentarz, Wrocław 2007, s. 690. 
kompetencję do korzystania z utworu. Przez zajęcie egzekucyjne oraz zajęcie zabezpieczające będziemy rozumieć czynność organu egzekucyjnego, na podstawie której następuje odebranie zobowiązanemu swobody rozporządzania przysługującym mu prawem majątkowym. Czynność egzekucyjna organu egzekucyjnego musi wynikać z roszczenia konkretnego wierzyciela wobec zobowiązanego. Nie ma znaczenia, że zobowiązany kwestionuje zasadność zajęcia.

Konsekwencją zajęcia egzekucyjnego i zajęcia zabezpieczającego jest nie tylko uzyskanie przez organ egzekucyjny prawa do rozporządzania zajętą częścią majątku zobowiązanego, ale też ograniczenie możliwości rozporządzania tym majątkiem przez zobowiązanego, który nie może wówczas np. zastawić zajętej rzeczy ruchomej lub dokonywać wypłat z zajętego rachunku bankowego. $\mathrm{W}$ wyniku zajęcia zabezpieczającego organ egzekucyjny uzyskuje tytuł prawny do rozporządzenia zajętym składnikiem majątku zobowiązanego, niezależnie od tego, w czyim posiadaniu - zobowiązanego lub innej osoby - on się znajduje ${ }^{44}$.

Rozporządzenie zajętymi egzekucyjnie prawami przez organ egzekucyjny ograniczone jest do wykonywania praw w zakresie niezbędnym do prowadzenia egzekucji, np. ściągnięcia wierzytelności na poczet egzekwowanego zobowiązania od dłużnika zajętej wierzytelności, zabezpieczenia dochodzonej należności. Prawo do rozporządzania utworem traktuje art. 17 pr. aut., według którego „korzystanie” na gruncie tego przepisu nie obejmuje pośredniej eksploatacji utworu, a przez prawo do rozporządzania utworem należy rozumieć wszystkie postacie czynności prawnych podmiotu autorskich praw majątkowych, na podstawie których inny podmiot uzyskuje na określonych warunkach kompetencje do korzystania $\mathrm{z}$ utworu ${ }^{45}$.

W świetle redakcji art. 17 pr. aut. wyróżnić można wzajemne relacje pojęć „,autorskie prawo majątkowe” i „prawo do wynagrodzenia”. Według ukształtowanej linii orzecznictwa sądowego niezapłacenie wynagrodzenia z tytułu korzystania z przedmiotu prawa autorskiego nie stanowi narusze-

44 Zob. W. Grześkiewicz, Komentarz do art. 1a) u.p.e.a..., s. 87.

45 J. Barta, R. Markiewicz, Prawo autorskie, Warszawa 2008, s. 92. 
nia autorskich praw majątkowych ${ }^{46}$. Z zarzutu naruszenia prawa autorskiego zwalnia wystąpienie do sądu przez korzystającego z żądaniem ustalenia stosownej wysokości wynagrodzenia. Oznacza to, że zajęte prawo podmiotowe $\mathrm{w}$ postaci wynagrodzenie u korzystającego z prawa autorskiego zobowiązanego może podlegać realizacji egzekucyjnej, jeżeli jest wymagalne, tzn. bezsporne.

Ustawodawca nałożył na organ egzekucyjny dodatkowy obowiązek w przypadku zajęcia poszczególnych praw. W sytuacji, gdy zajęte prawo własności intelektualnej podlega rejestracji w Urzędzie Patentowym RP, organ egzekucyjny przesyła do Urzędu Patentowego RP wniosek o dokonanie we właściwym rejestrze wpisu o zajęciu prawa. W zakresie praw własności przemysłowej podlegających egzekucji administracyjnej w trybie art. 96g-96i u.p.e.a. rejestracji w Urzędzie Patentowym RP podlegają: patent, wzór użytkowy, znak towarowy, topografia układu scalonego (art. 315 ust 1 ust 1p.w.p.) oraz wzór zdobniczy (art. 315 ust 1 p.w.p.). Zatem dokonując zajęcia $\mathrm{z}$ prawa $\mathrm{z}$ patentu, prawa ochrony na wzór użytkowy, prawa z rejestracji topografii, prawa z rejestracji znaku towarowego, prawa z rejestracji topografii układu scalonego, organ egzekucyjny przesyła do Urzędu Patentowego RP wniosek o wpis informacji o zajęciu prawa do właściwego rejestru. Wpis zajęcia dokonywany jest do: rejestru patentowego, rejestru wzorów użytkowych, rejestru wzorów przemysłowych, rejestru znaków towarowych, rejestru znaków geograficznych, rejestru topografii układów scalonych ${ }^{47}$.

Zajęte w trybie art. 96g u.p.e.a. prawa podlegają sprzedaży w trybie przewidzianym w dziale II rozdziału 6 oddziału 2 u.p.e.a. regulujących sprzedaż ruchomości.

W toku prowadzonego postępowania egzekucyjnego zobowiązany na mocy z art. 67a § 2 u.p.e.a. ma obowiązek udzielać organowi egzekucyjnemu wszelkich wyjaśnień niezbędnych do dochodzenia należności pieniężnej oraz żądać informacji o przysługujących jemu wierzytelnościach

46 Zob. postanowienie Sądu Najwyższego z dnia 9 lutego 1973 r., II CZ 4/73, OSNC 1973, nr 12, poz. 222.

47 Zob. M. Romańska, O. Dumnicka, Postępowanie zabezpieczajq̨e i egzekucyjne, Warszawa 2010, s. 732. 
z tytułu zajętego prawa własności intelektualnej (art. 36 u.p.e.a.). W sytuacji zajęcia autorskiego prawa majątkowego bądź praw pokrewnych organ egzekucyjny uprawniony jest do żądania od zobowiązanego wyjaśnienia, czy zarządzenie zajętym prawem oraz wykonywanie uprawnień wynikających z ustawy o prawie autorskim i prawach pokrewnych jest powierzone tzw. organizacji zbiorowego zarządzania, stowarzyszeniu zrzeszającemu twórców, artystów, wykonawców, producentów lub organizacje radiowe i telewizyjne ${ }^{48}$.

W sytuacji, gdy przedmiotem zajęcia dokonanego na podstawie art. 96g u.p.e.a. są korzyści z prawa własności intelektualnej, a protokół zajęcia wraz z zawiadomieniem o zakazie rozporządzania zajętymi prawami doręczony został zobowiązanemu na podstawie art. 96g § 5 pkt 1 i 3 u.p.e.a, uzasadnione będzie stanowisko, że skutki zajęcia dla zobowiązanego powstaną $\mathrm{z}$ chwilą dokonania tego zajęcia, $\mathrm{tj}$. $\mathrm{z}$ chwilą podpisania protokołu zajęcia przez poborcę skarbowego, a także zobowiązanego lub świadków.

Czynności egzekucyjne w ramach prowadzonego postępowania egzekucyjnego z wierzytelności prawa własności intelektualnej mogą być podjęte wobec dłużnika zobowiązanego w tym organizacji zbiorowego zarządzania, której powierzono zarządzanie i ochronę zajętego prawa oraz wykonywanie uprawnień wynikających z ustawy o prawie autorskim i prawach pokrewnych. W stosunku do dłużnika zajętej wierzytelności zajęcie wierzytelności jest skuteczne z chwilą doręczenia mu zawiadomienia o zajęciu (art. 89 i n. u.p.e.a.). Zawarcie przez zobowiązanego oraz dłużnika zajętej wierzytelności umowy o odroczeniu terminu płatności rat zajętej wierzytelności nie stanowi okoliczności uzasadniającej odmowę dłużnika zajętej wierzytelności przekazania organowi egzekucyjnemu zajętej kwoty. Umowa taka zawarta po zajęciu wierzytelności stanowi naruszenie zakazu rozporządzania wierzytelnością przez zobowiązanego i nie może wywierać skutków w odniesieniu do postępowania egzekucyj-

48 Zob. obwieszczenie Ministra Kultury i Dziedzictwa Narodowego z dnia 26 marca 2009 r. w sprawie ogłoszenia decyzji Ministra Kultury i Dziedzictwa Narodowego o udzieleniu i o cofnięciu zezwoleń na podjęcie działalności organizacji zbiorowego zarządzania prawami autorskimi lub prawami pokrewnymi (M.P. Nr 21, poz. 270). 
nego. W konsekwencji organ egzekucyjny może ściągnąć zajętą kwotę w drodze egzekucji administracyjnej z całego majątku dłużnika wierzytelności ${ }^{49}$.

Z kolei jeżeli prawo własności intelektualnej zostało zajęte przez inny organ egzekucyjny, dochodzi wtedy do zbiegu egzekucji. W tej sytuacji będą miały zastosowanie przepisy u.p.e.a. o zbiegu egzekucji. W przypadku zbiegu egzekucji administracyjnej i sądowej do tej samej rzeczy albo prawa majątkowego egzekucje do tej rzeczy albo prawa majątkowego prowadzi łącznie sądowy organ egzekucyjny albo organ egzekucyjny, który jako pierwszy dokonał zajęcia, a w razie niemożności ustalenia tego pierwszeństwa - organ, który dokonał zajęcia na poczet należności w wyższej kwocie (art.62 u.p.e.a). Z kolei w przypadku zbiegu egzekucji administracyjnych do tej samej rzeczy albo prawa majątkowego egzekucje do tej rzeczy albo prawa majątkowego egzekucje do tej rzeczy albo prawa majątkowego prowadzi łącznie organ egzekucyjny, który jako pierwszy dokonał zajęcia, a w razie niemożności ustalenia tego pierwszeństwa - organ, który dokonał zajęcia na poczet należności w wyższej kwocie (art. 63 u.p.e.a.).

W kwestii określenia osób odpowiedzialnych, podstaw i zakresu odpowiedzialności za naruszenie prawa autorskiego mają zastosowanie przepisy kodeksu cywilnego dotyczące czynów niedozwolonych, np. wskazanych w art. 422 czy art. 441 k.c. Zgodnie art. 103 § 2 u.p.e.a. „za uszkodzenie, zniszczenie lub zaginięcie zajętej ruchomości w czasie transportu odpowiada organ egzekucyjny, chyba że wynikły wskutek przypadku lub siły wyższej”. Europejski Trybunał Sprawiedliwości w wyroku z dnia 18 grudnia 2007 r., C-314/06 ${ }^{50}$ uznał, że „pojęcie siły wyższej” w rozumieniu art. 14 ust. 1 zdanie pierwsze dyrektywy horyzon-

49 Zob. wyrok NSA OZ w Gdańsku z dnia 4 października 1996 r., SA/Gd 3296/95 (Lex Polonica nr 342544).

50 Zob. K. Lasiński-Sulecki, Komentarz do wyroku Europejskiego Trybunału Sprawiedliwości z dnia 18 grudnia 2007 r. w sprawie Société Pipeline Méditerranée et Rhône (SPMR) przeciwko Administration des douanes et droits indirects, Direction nationale du renseignement et des enquêtes douanière (DNRED), (C-314/06), „Przegląd Orzecznictwa Podatkowego” 2008, z. 2, poz. 31, s. 203-205. 
talnej $^{51}$ „obejmuje okoliczności niezależne od właściciela składu, nadzwyczajne i nieprzewidywalne, których konsekwencji nie można było uniknąć, pomimo dochowania w tym celu należytej staranności”. Pojęcie przypadku w literaturze definiowane jest jako pojęcie przeciwstawne wobec zdarzenia zawinionego, będącego często następstwem świadomego działania osób trzecich ${ }^{52}$.

\section{Wnioski końcowe}

Dotychczasowe doświadczenia związane z wprowadzeniem środka egzekucyjnego - egzekucji z tzw. praw własności - pokazują, że najłatwiej zapisać, jak i od kiedy dana instytucja prawna ma funkcjonować. Nie oznacza to jednak, że zacznie ona faktycznie działać. W praktyce organów egzekucyjnych środek ten, ze względu na krótki okres od wprowadzenia do ustawy, uznać należy za „martwy”. Z jednej strony organy egzekucyjne zdają sobie w pełni sprawę z jego zawiłości, z drugiej strony prawo własności intelektualnej zaczyna odrywać rolę nieporównywalnie większą, aniżeli było to dotychczas w stosunkach społecznych, ekonomicznych, a nawet stało się instrumentem oddziaływania w stosunkach politycznych. W literaturze przedmiotu podnoszona jest kwestia wykorzystania własności intelektualnej i jej ochrony poprzez patenty i licencje jako istotnego instrumentu we wpływów korporacyjnych grup interesów ${ }^{53}$. W warunkach procesu globalizacji i Internetu wzrost znaczenia wykorzystania własności intelektualnej i jej ochrony może mieć wręcz charakter „rewolucyjny”, co będzie miało wpływ na potrzebę stworzenia nowych regulacji dochodzenia należności wierzyciela publicznego z praw własności intelektualnej.

51 Dyrektywa 92/12/EWG Rady z dnia 25 lutego 1992 r. w sprawie ogólnych ustaleń dotyczących wyrobów objętych podatkiem akcyzowym, ich przechowywania, przepływu oraz kontrolowania (Dz.Urz. WE L 76 z 23 marca 1992, s. 1), zmienionej przez Dyrektywę 94/74/WE Rady z dnia 22 grudnia 1994 r. (Dz.Urz. WE L 365 z 31 grudnia 1994, s. 46).

52 W. Czachórski, Prawo zobowiqzań w zarysie, Warszawa 1970, s. 277.

53 J.E. Stiglitz, Wizja sprawiedliwej globalizacji. Propozycja usprawnień, Warszawa 2007, s. 133 i n. 
Zagadnienia te jednak wykraczają poza ramy niniejszego opracowania. Podniesione kwestie mają charakter wstępny i z założenia dokonanie częściowej analizy zagadnienia zawartego w tytule opracowania. Ujawnia one jednak złożoność podjętego problemu stosowania administracyjnego środka egzekucyjnego.

Z chwilą wstąpienia Polski do Unii Europejskiej należy wziąć pod uwagę, że stosownie do art. 66 i 68 Układu Europejskiego ${ }^{54}$ Polska była zobowiązana do zbliżenia swego prawa do istniejącego we Wspólnotach. Powołane przepisy - przewidując, że istotnym warunkom wstępnym integracji gospodarczej Polski ze wspólnotami było zbliżenie istniejącego i przyszłego ustawodawca Polski do ustawodawca istniejącego we Wspólnotach - określały, że obejmuje ono prawo własności intelektualnej. Harmonizacja, dokonywana zarówno przez zmianę przepisów, jak i w drodze orzecznictwa sądowego, jest procesem ewolucyjnym i będzie miała wpływ na kształt egzekucji z praw własności intelektualnej.

Oto główne - według mnie - kierunki zmian w egzekucji należności pieniężnych w trybie administracyjnego postępowania egzekucyjnego.

Ustawa o postępowaniu egzekucyjnym jednocześnie jako akt prawa procesowego i materialnego jest dość skomplikowany w stosowaniu przez uczestników egzekucji administracyjnej. Został on uchwalony w innych realiach społeczno-gospodarczych. W tych warunkach regulacje prawne zawarte w ustawie egzekucyjnej powinny być dostosowane do nowej sytuacji gospodarki rynkowej, powinny zmierzać w kierunku ich dostosowania do aktualnej sytuacji gospodarczej i politycznej, uproszczenie procedur prowadzonego administracyjnego postępowania egzekucyjnego. Nowe regulacje prawne poprzez nowelizację ustawy zasadniczej nie powinny być dokonywane w formie cząstkowych unormowań prawnych. Powinny one być przyporządkowane idei skuteczności egzekucji, jednak przy poszanowaniu europejskich standardów ochrony praw własności. Obecnie obowiązujący akt prawny ma ponad 50 lat, a znaczna liczba zmian nie wpływa na korzyść i jego przejrzystość.

54 Ustanowienie Stowarzyszenia między Rzeczypospolitą Polską $\mathrm{z}$ jednej strony a Wspólnotami Europejskimi z ich Państwami Członkowskimi z drugiej strony z dnia 16 grudnia 1991 r. (zał. do Dz.U. z 1994 r. Nr 11, poz. 38). 
Wprowadzenie nowych środków w egzekucji administracyjnej miało na celu poprawę skuteczności egzekucji podatków, co w konsekwencji miało wpłynąć na poprawę stanu finansowego budżetu państwa. Takie były założenia wprowadzanych zmian. Środek egzekucyjny, egzekucja z autorskich praw majątkowych i praw pokrewnych oraz z własności przemysłowych powinna ograniczać się do egzekucji z korzyści z tych praw, tj. osiąganych w formie pieniężnej wynagrodzenia, tantiem lub rzeczowej; wynagrodzenia, aportów lub udziałów wnoszonych do podmiotów gospodarczych.

W egzekucji administracyjnej realizowana jest zasada ogólna poszanowania minimum egzystencji, w ramach której uwzględnione są składniki majątku zobowiązanego zwolnione ustawowo spod egzekucji oraz wyliczenie wyjątków od tego zwolnienia. Ze względu na specyficzny charakter wartości intelektualnej wskazane jest ustawowe zagwarantowanie w szerszym zakresie ochrony praw majątkowych poprzez np. wyłączenia spod egzekucji składników majątkowych służących twórcy do wykonywania pracy, zwiększenia wysokości kwoty pieniężnej, która nie podlega egzekucji.

\section{Bibliografia:}

Barta J., Czajkowska-Dąbrowska M., Ćwiąkalski Z., Markiewicz R., Traple E., Prawa autorskie i prawa pokrewne, Zakamycze, Kraków 2005.

Barta J., Markiewicz R., Prawo autorskie i prawa pokrewne, Oficyna Wolters Kluwer business, Warszawa 2008.

Barta J., Markiewicz R., Prawo autorskie, Oficyna a Wolters Kluwer business, Warszawa 2010.

Barta J., Markiewicz R., Prawo autorskie, Oficyna a Wolters Kluwer business, Warszawa 2008.

Bojanowski E., Wykonanie zastępcze w egzekucji administracyjnej, Wydawnictwo Prawnicze, Warszawa 1975.

Czachórski W., Prawo zobowiqzań w zarysie, Państwowe Wydawnictwo Naukowe, Warszawa 1970.

du Vall M., Prawo patentowe, Oficyna Wolters Kluwer business, Warszawa 2008. 
Faryna M. Komentarz do art. $96 \mathrm{~g}$ u.p.e.a., [w:] D.R. Kijowski (red.) Ustawa o postępowaniu egzekucyjnym administracji. Komentarz, Lex a Wolters Kluwer business, Warszawa 2010.

Golat R., Prawo autorskie. Komentarz dla praktyków, Ośrodek Doradztwa i Doskonalenia Kadr, Gdańsk 2008.

Gronowski S., Prawo własności przemysłowej. Zagadnienia ogólne i proceduralne, Polska Izba rzeczników Patentowych, Warszawa 2002.

Grześkiewicz W. Komentarz do art. 1a) u.p.e.a., [w:] D.R. Kijowski (red.), Ustawa o postępowaniu egzekucyjnym $w$ administracji. Komentarz, Lex a Wolters Kluwer business, Warszawa 2010.

Hauser R., Skoczylas A., Postępowanie egzekucyjne w administracji. Komentarz, Wydawnictwo C.H. Beck, Warszawa 2011.

Jakubecki A., Postępowanie zabezpieczające w sprawach z zakresu prawa własności intelektualnej, Zakamycze, Kraków 2002.

Jankowiak D., Ustawa o postępowaniu egzekucyjnym w administracji, Komentarz 2007, Wrocław 2007.

Lasiński-Sulecki K., Komentarz do wyroku Europejskiego Trybunału Sprawiedliwości z dnia 18 grudnia 2007 r. w sprawie Société Pipeline Méditerranée et Rhône (SPMR) przeciwko Administration des douanes et droits indirects, Direction nationale du renseignement et des enquêtes douanière (DNRED), (C-314/06), „Przegląd Orzecznictwa Podatkowego” 2008, z. 2, poz. 31, ss. 203-205.

Masternak M., Biegły w postępowaniu podatkowym, „Kwartalnik Prawa Publicznego” 2001, nr 2, wersja on-line, http://lex.pl/czasopisma.

Przybysz P., Postępowanie egzekucyjne w administracji. Komentarz, LexisNexis, Warszawa 2009.

Rączka P. Egzekucja z autorskich praw majq̨tkowych i praw pokrewnych oraz z praw własności przemysłowej, [w:] T. Jędrzejewski, M. Masternak, P. Rączka, Administracyjne postępowanie egzekucyjne, TNOiK, Toruń 2006.

Romańska M., Dumnicka O., Postępowanie zabezpieczajqce i egzekucyjne, C.H. Beck. Warszawa 2010.

Sieńczyło-Chlabicz J., (red.), Prawo własności intelektualnej, LexisNexis, Warszawa 2009.

Skubisz R. (red.), Własność przemysłowa. Orzecznictwo Trybunału Sprawiedliwości Wspólnot Europejskich, Sqqu Pierwszej Instancji i Urzędu Harmoni- 
zacji Rynku Wewnętrznego z komentarzami, Oficyna a Wolters Kluwer business, Warszawa 2008.

Stiglitz J.E., Wizja sprawiedliwej globalizacji. Propozycja usprawnień, Wydawnictwo Naukowe PWN, Warszawa 2007.

Traple E. [w:] J. Barta (red.), System Prawa Prywatnego. Prawo autorskie, t. 13, C.H. Beck, Warszawa 2007.

Włodarczyk W., Egzekucja administracyjna z praw własności intelektualnej, [w:] J. Niczyporuk, S. Fundowicz, J. Radwanowicz (red.), System egzekucji administracyjnej, C.H. Beck -Verba, Warszawa 2004.

Wojciechowska A., Osobiste prawa autorskie w stronę zmiany paradygmatu, [w:] J. Barta, R. Markiewicz, Prawo autorskie a postęp techniczny, Kraków 1999.

Wronkowska S., Zieliński M., Problemy i zasady redagowania tekstów prawnych, Urząd Rady Ministrów, Warszawa 1993. 